\title{
O QUE É PERVERSÃO?
}

\section{Cibele Prado Barbieri Psicanalista. Membro do Círculo Psicanalítico da Bahia.}

\begin{abstract}
"Tenho o direito de gozar de teu corpo, pode dizer-me qualquer um, e exercerei esse direito, sem que nenhum limite me detenha no capricho das extorsões que me dê gosto de nele saciar." (Lacan, Kant com Sade) ${ }^{1}$
\end{abstract}

Falar de perversão costuma provocar sono nos ouvintes, certamente porque mobiliza nossos restos de perversão e nossos recalques. Em compensação, ouvir o perverso é sempre de tirar o sono, pois ele tem um jogo de cintura, às vezes tão sutil, para manobrar as coisas a seu modo, que se torna imperceptível para os incautos. Não me refiro apenas aos grandes perversos descobertos e declarados, ou aos enrustidos, políticos ou criminosos. Refiro-me também ao perverso que não se acha perverso, que não percebe seu modo manipulador e precisa que alguém o confronte, para poder dar-se conta de como ele lida com suas frustrações e angústias de uma forma que, tecnicamente, chamamos perversa.

Sabemos desde Freud que, se não o somos mais, já fomos um dia perversos polimorfos e não estamos isentos da essência perversa da nossa fantasia fundamental. Talvez possamos daí entender as dificuldades em lidar com este conceito que, ao longo do tempo e dos interesses da ciência, acabou por ser excluído do glossário psiquiátrico.

Este nome não figura mais na Classificação de Transtornos Mentais e de Comportamento da CID-10², criada pela Organização Mundial de Saúde. No DSM-IV encontramos um verbete que explica que a Psiquiatria substituiu o termo perversão por "parafilia", por causa de seu peso pejorativo no senso comum e [...] para amenizar o estigma que a palavra perversão coloca sobre a sexualidade humana normal", deixando o termo perversão para o uso jurídico ${ }^{4}$.

\footnotetext{
${ }^{1}$ Máxima sadeana, segundo Lacan, no texto Kant com Sade; 1988. p.780.

${ }^{2}$ Organização Mundial de Saúde; 1993.

${ }^{3}$ Diagnostic and Statistical Manual of Mental Disorders, Classificação (e descrição) das doenças mentais da Associação Norte-Americana de Psiquitria.

${ }^{4}<$ http://virtualpsy.locaweb.com.br/dicionario_janela.php?cod=421e http://virtualpsy.locaweb.com.br/index.php?sec=78\&art=166>.
} 
Elisabeth Roudinesco, em seu recém-lançado livro, A parte obscura de nós mesmos: uma história dos perversos assinala que "no que se refere à estrutura, denominação e significação, a perversão só foi estudada pelos psicanalistas" 5 .

Entretanto, os saberes reunidos sob este termo antecedem o advento da psicanálise e da psiquiatria em vários séculos e se inscrevem no discurso leigo, teológico e jurídico como questão que sempre provocou interesse pelas ambigüidades que apresenta.

A palavra perversão é muito antiga e sua polissemia é extensa. Segundo o Online Etymologycal Dictionary ${ }^{6}$, o sentido vinculado a crenças religiosas predomina no uso mais antigo do termo com o significado de "desviar alguém de uma crença religiosa correta para uma falsa ou errônea" e, ainda, corromper, tomar o caminho errado.

O adjetivo, perverso, que existe desde 1369 com o significado de mau, ruim, pecaminoso, vicioso e também malvado, pernicioso, tem, ao mesmo tempo, antiteticamente, o sentido de muito bom, excelente (em inglês: wicked; “The Wicked One”, o capeta).

Oriundo da teologia moral cristã, este termo refere-se em sua origem, segundo Mario Fleig, "a todas as formas de pecar quanto ao sexo. A suposição de uma lei natural que imprime à sexualidade o objetivo único da procriação introduz o sentido de perversão como inversão do suposto natural "7. Esta idéia é também relacionada à antiga tradição da lei comum inglesa, engajada na doutrina de que nenhuma atividade sexual é justificável, a não ser que seu objetivo seja a procriação.

No desenvolvimento que Roudinesco faz da polissemia do termo perversão, predominam os sentidos antitéticos:

[...] o pervertedor era em primeiro lugar uma criatura dúbia, atormentada pela figura do Diabo, mas ao mesmo tempo habitada por um ideal do bem que ele não cessava de destruir, a fim de oferecer a deus, seu senhor e seu carrasco, o espetáculo de seu próprio corpo reduzido a um dejeto.

Embora vivamos num mundo em que a ciência ocupou o lugar da autoridade divina, o corpo o da alma, e o desvio o do mal, a perversão é sempre, queiramos ou não, sinônimo de perversidade. E, sejam quais forem seus aspectos, ela aponta sempre, como antigamente, mas por meio de novas metamorfoses, para uma espécie de negativo da liberdade: aniquilamento, desumanização, ódio, destruição, domínio, crueldade, gozo. ${ }^{8}$

\footnotetext{
${ }^{5}$ Roudinesco; 2008. p.7.

${ }^{6}$ Roudinesco; 2008. p.7.

${ }^{7}$ Fleig; 2008. p. 15

${ }^{8}$ Roudinesco; 2008. p. 10-11. Grifo nosso.
} 
Ela continua citando, ainda, uma definição muito interessante do Littré: “Transformação do bem em mal. A perversão dos costumes. Distúrbio, perturbação. Há perversão [...] da visão na diplopia. A diplopia é uma alteração da visão, uma má convergência, que faz com que vejamos dois objetos em lugar de um" 9 .

Chama a nossa atenção, nesse trecho, a ambigüidade dessa posição em relação à liberdade de ação, a convergência de princípios opostos e contraditórios em relação ao princípio lógico da não-contradição e o exemplo dado pelo Littré, que estabelece relação entre perversão e diplopia, marcando também esta dualidade paradoxal.

Com o surgimento da psiquiatria, surge um sentido psicológico, de desvio comportamental. São criadas classificações que descrevem e isolam tipos de perversões especificamente sexuais nas quais a satisfação se diferencia do relacionamento heterossexual considerado normal.

Nesse contexto em que aparece, segundo Roudinesco, uma verdadeira obsessão em relação à masturbação infantil, à histeria e à homossexualidade ${ }^{10}$, consideradas perversões, a psicanálise surge propondo de saída uma construção teórica da perversão que se situa como marginal ao campo da biologia e da medicina, e também destituída do sentido religioso e moral. Aplicando a tese da etiologia sexual e do recalque, Freud faz o contraponto entre a perversão e a neurose.

Não é à toa que ele inicia os "Três ensaios" anos de silêncio desde a publicação da "Psicopatologia da vida cotidiana" [1901]. Provavelmente, ele discerniu no cotidiano as raízes perversas da sexualidade e o avesso do recalque, capazes de confirmar suas hipóteses. Inicia seu ensaio em uma forma sutil e elegante de quem introduz um assunto polêmico, carregado de preconceitos morais e éticos, e termina dizendo, no Resumo, que a neurose é o negativo da perversão ${ }^{12}$.

Vou arriscar afirmar, porque desconheço outra referência, que Freud inaugura com este ensaio um novo saber sobre a perversão, que permite ver nas ambigüidades que a cercam sua característica fundamental.

\footnotetext{
${ }^{9}$ Conferir Roudinesco; 1966. v.5. Grifo nosso.

${ }^{10}$ Conferir Roudinesco; 1966. v.5. Grifo nosso

${ }^{11}$ Freud; 1973; v. II, p. 1.172.

${ }^{12}$ Freud; 1973; v. II, p. 1.172.
} 
Afinal de contas, diz ele, "o que temos que encarar neste assunto é um campo de fenômenos como qualquer outro"13. "Aqueles que limitam o sentido do sexual aos objetivos da procriação e do prazer genital, sacrificam [assim] a compreensão das perversões e do enlaçamento que existe entre estas, a neurose e a vida sexual normal" ${ }^{14}$. "Por mais infames que possam ser [as perversões], por mais nítido que se faça o contraste com a atividade sexual normal, uma reflexão tranqüila mostrará que, um ou outro traço de perversão raramente está ausente da vida sexual das pessoas normais"

Talvez a bibliografia sobre a perversão prolifere constantemente no campo da psicanálise, porque, ao considerarmos a perversão como um efeito da subjetividade, temos que articular este modo particular de o sujeito fazer uso dos recursos que a língua oferece, tanto quanto o modo particular da neurose ou da psicose.

Apesar de o discurso da pós-modernidade trazer novas roupagens para os sintomas, os parâmetros fundamentais aí implicados continuam os mesmos. Isto torna possível entendermos que fenômenos e expressões aparentemente diferentes possam ser recobertos por um mesmo termo quando analisados à luz dos conceitos psicanalíticos, apesar das novas apresentações sintomáticas que nascem da proliferação de novos objetos de prazer e de gozo.

Para melhor justificar essas afirmações, partirei do básico. Em Freud, "a disposição para as perversões é a disposição originária e universal da pulsão sexual dos seres humanos", ${ }^{16}$ o que torna insuficiente de saída a concepção de inversão contra a natureza. No ser falante, a natureza está subvertida pela plasticidade do objeto pulsional, que admite toda sorte de variações. A sexualidade é perversa polimorfa, na medida em que se organiza em torno de objetos parciais, e isto não deve ser confundido com a perversão em sentido estrito, pois toda criança é perversa polimorfa, mas nem todas se tornam perversas na maturidade. $\mathrm{O}$ que Freud observa é que, ao longo do percurso da criança rumo à maturidade, ela adotará diferentes modos de lidar com esta disposição a partir da descoberta da diferença anatômica entre os sexos, dependendo do contexto edípico em que está inserida.

Se a criança não faz uma representação da diferença ou rejeita e expulsa esta representação para fora do campo das significações, este mecanismo, chamado por Freud de verwerfung (ou foraclusão), promoverá os efeitos que conhecemos como psicose.

\footnotetext{
${ }^{13}$ Freud; 1976. v. XVI, p. 359.

${ }^{14}$ Freud; 1976. v. XXI, p. 43.

15 Freud; 1976. v. XVI, p. 377.

${ }^{16}$ Freud; Fleig. 2008. 59-60. v. II, p. 1.172. Tradução livre do espanhol.
} 
Se ela faz a representação, mas relega essa idéia ao esquecimento, ou seja, ao inconsciente, barrando seu acesso à consciência para não saber mais nada sobre ela, Freud chama a isto verdrängung (ou recalcamento), que resulta na contenção da pulsão pela interdição de sua satisfação, provocando o sintoma neurótico.

Mas se ela simplesmente recusa essa representação como verdadeira e neutraliza sua ação e seus efeitos sem, contudo, excluí-la do campo das representações e da consciência, isto, para Freud, é verleugnung, cuja tradução é problemática.

$\mathrm{Na}$ tradução para o português, utilizou-se, principalmente, o termo recusa, mas também renegação ou rejeição; termos que implicam a negativização de uma representação, no sentido de que a idéia é mantida na consciência, mas ao mesmo tempo sua veracidade é negada, negativizada. Na tradução para o francês, Lacan propõe o termo dementi, desmentir, que tem como vantagem o sentido de desdizer a veracidade do que foi dito com outro dito, evitando confundi-lo com a denegação (verneinung), que tem um efeito de retificação de uma afirmação.

Freud diz, no Esboço de Psicanálise, ${ }^{17}$ que esse mecanismo responde especificamente à descoberta da castração feminina e está presente nas várias formas de perversão, permitindo que duas idéias opostas coabitem o mesmo eu "pacificamente". É o que será fundamentado como "clivagem do eu" em seu artigo seguinte, também de 1938. "Duas atitudes - diz ele que [...] persistem ao longo da vida lado a lado sem se influenciarem reciprocamente" ${ }^{\text {, }}$, aliás, como na diplopia, que faz com que vejamos dois objetos em lugar de um. Na clivagem do eu, convergem duas imagens: objeto presente e ausente, duas representações opostas que coexistem; uma afirmação e um desmentido.

Serge André afirma que a perversão "é algo totalmente diferente de uma entidade clínica: ela é um certo modo de pensar. Um pensamento cuja essência demonstrativa decorre das relações do perverso com a fantasia e com a Lei" ${ }^{19}$.

Não apenas um sujeito, mas também um sistema de pensamento podem ser organizados segundo essa mesma lógica.

Nessa forma discursiva, trata-se de eliminar a ausência, através de uma relação particular com a linguagem pela qual o sujeito estabelece uma ética própria, em acordo com

\footnotetext{
${ }^{17}$ Freud; 1976. v. XXIII

${ }^{18}$ Freud; 1976. v. XXIII.

${ }^{19}$ André; 1995. p. 311-312.
} 
seu desejo como regra, e inclui um desafio à interdição instituída pela norma geral: a Lei do Pai.

Pode parecer que esse poder desafiante torne possível um gozo sexual garantido. Entretanto, isto não isenta o perverso de um drama, pois, diante da impossibilidade de recorrer ao pai enquanto função reguladora, ele termina por cair sob a dominação de outra regra: o gozo materno. Sabemos que, se não há castração, não há falta; se nada falta, não há desejo e, se não há desejo, há gozo.

Esse é um gozo arbitrário e autocrático, que se revela uma lei muito mais coercitiva que a lei pacificadora do pai. Esta lei, explicitada no discurso sadiano, não é outra senão o direito de gozar do corpo do outro sem limites, e seu efeito lógico é a instauração da instância da exceção, do Um, que escapa à castração e não se divide diante do desejo: o absoluto que tudo pode cuja fórmula Freud elaborou em "Totem e tabu"20.

$\mathrm{Na}$ verdade, poderíamos dizer que, paradoxalmente, o perverso sofre de uma busca ávida de Lei, pois o norteamento que deveria vir do Pai não se sustenta. Podemos assim entender que o desejo da mãe enquanto fálica convoca à pulsão de morte, porque promove o apagamento subjetivo na criança tomada como objeto de satisfação. Quando o desejo do pai fracassa em sua função de limitar o gozo da mãe para alinhar a criança na direção do desejo de vida, a face silenciosa da pulsão, a de morte, prevalece.

É o que aprendemos com as biografias e os escritos de grandes perversos como Sade, Mishima, Gide e outros ${ }^{21}$, que nos ensinam como afirmar a presença daquilo que falta, sustentando o dito com uma representação capaz de funcionar como garantia: a isto chamamos fetiche, que pode ser um objeto inanimado ou apenas outro ser, inanimado.

Esse contexto infantil, nada pueril, produzirá conseqüências profundas na estruturação da subjetividade, que se expressarão tanto no nível do discurso quanto do ato, pois estarão sempre sobredeterminadas por esta lógica de desrealização da diferença e da falta.

Esse modo de lidar com "[...] tudo aquilo que se ordena em torno da ausência e da presença do falo" 22 , e que se refere "[...] a um contexto dialético tão sutil, tão composto, tão rico de compromissos e tão ambíguo quanto o de uma neurose",23, nos diz Lacan, coloca em jogo as mesmas fantasias perversas que, no neurótico, seriam barradas pela operação do

\footnotetext{
${ }^{20}$ Freud; 1973. v. II

${ }^{21}$ Millot; 2004.

${ }^{22}$ Lacan; 1995. p. 156.

${ }^{23}$ Lacan; 1999. p. 239.
} 
recalque. Mas o fato de o perverso conseguir iludir a castração não o salva da angústia, que ressurge incessante e sutilmente, exigindo dele, às vezes, até mais compromissos do que do neurótico.

Para ilustrar um pouco os infortúnios dessa posição, vou narrar um episódio que se repete na vida de um rapaz, na faixa dos 30 anos, que é muito inteligente e até bem- sucedido profissionalmente. No seu dia-a-dia, é cumpridor dos deveres, funcionário responsável que sustenta, praticamente sozinho, a família desde que o pai entrou em crise financeira, há muitos anos. Na infância, era o neto padrão: bom comportamento, viril, o sucesso da família. Na vida amorosa, não sofre problemas de desempenho sexual, mas seus relacionamentos foram muito poucos e todos fugazes; seus amores, platônicos e intermináveis, sempre se desenrolaram à distância. É muito cavalheiro e inibido com as garotas, mesmo quando elas tomam a iniciativa da conquista, mas isto nada tem a ver com o desejo sexual. O fato é que seus raros namoros definham rapidamente.

Ao final da adolescência, foi deixado por seus pais morando de favor com uma família de amigos da avó, nada íntimos dele, pois sofreram uma decadência financeira completa que os forçou a mudar para o interior. A matriarca, mãe adotiva de sua mãe, tomava todas as decisões, desconsiderando seu pai que, profissionalmente fracassado e sem nenhuma iniciativa, necessitava da sua ajuda e submetia-se a suas determinações.

Isolado da família, numa quase indigência, quando começou a trabalhar passou a beber com freqüência e freqüentar casas de massagem onde fazia sexo com prostitutas. Já morando sozinho, esta atividade se intensificou e a ela foram-se incorporando detalhes que compõem uma cena que obedece a um verdadeiro roteiro que se repete ciclicamente, com intervalos cada vez menores. Quando a situação financeira ficou calamitosa, pelas dívidas impagáveis acumuladas, a mãe descobre o que está acontecendo e volta com a família para apoiá-lo, mas sustentada por ele e pela avó, sempre que necessário.

Esse rapaz vem ao analista por uma demanda da mãe, não há uma queixa clara; o primeiro período de análise é, verdadeiramente, de entrevistas preliminares e, dura pouco. Ele não entra na associação livre, não se implica e se limita aos fatos objetivos. Após um intervalo retorna e então se implica no processo. Mas o progresso é sempre difícil, pois há um hiato, associativo e lógico, entre a sua vida cotidiana e os episódios que constituem o motivo de sua busca. Esses episódios obedeciam a uma seqüência que se foi desenvolvendo ao longo do 
tempo, e, quando a análise se iniciou, podiam ser descritos como uma série ritualizada de procedimentos que geravam problemas, mas não culpa.

Tudo começava com uma saída para se divertir com amigos, uma festa ou um show, onde ele encontrava namoradas em potencial. Após alguns copos de bebida, sentia-se incômodo no ambiente; de repente ele sumia, segundo suas palavras. Ia para uma boate onde escolhia duas ou três prostitutas e as levava para um motel. Lá eles consumiam bebidas, cigarros, drogas e ficavam muitas horas, até dias, pois ele perdia a noção de tempo.

A análise incita ao caminho associativo e revela que a escolha das prostitutas tinha como base a suposição de que elas gostassem de beber e se drogar. Ligado a isso, surgem duas associações: a lembrança da mãe dançando alcoolizada nas festas e as brincadeiras masturbatórias secretas com as amiguinhas da infância. Neste roteiro, a consumação do ato sexual nem sempre acontece, segundo ele, por causa do consumo excessivo de bebida e drogas e, muitas vezes, os encontros envolvem "conversas" que poderiam render uma relação de amizade. Algumas mulheres chegaram a se oferecer para sair com ele de graça se ele quisesse, mas ele rejeita.

Em algum momento, a cena se interrompia como se acordasse de um sonho, diz ele, se dava conta da hora, de onde estava e tratava de sair dali o mais rapidamente possível. Como invariavelmente não tinha dinheiro para pagar a conta, quando seu crédito acabou, sem cheques, sem cartões, tinha que recorrer à mãe, à avó. Chegou a pagar com aparelhos eletrônicos de sua casa e, no extremo, pedir empréstimo a amigos, o que sempre o aterrorizou, pois ele deve manter-se anônimo.

Como conclusão, momento de clímax desse roteiro, a semana seguinte é de ressaca física e moral. Além dos efeitos da bebida e, principalmente, das drogas, às quais não recorre em nenhuma outra situação, pensamentos persecutórios o invadem, antecipando o perigo iminente de ser identificado, reconhecido e denunciado publicamente e, na seqüência dos sentimentos de culpa, ele se vê como dejeto. Mas isto não impede que ele repita, muito em breve, tudo exatamente da mesma forma. Descobrimos que a ressaca passa rápido e não se refere ao conteúdo de seus atos, mas ao medo de ser descoberto e desmoralizado.

A volta à análise acontece num desses momentos quando, horrorizado, se dá conta de que está se hospedando na casa de um traficante que se põe a serviço dele, satisfazendo todas as suas demandas para que o ritual se realize perfeitamente. $\mathrm{O}$ horizonte de degradação que se desenha neste ato se torna claro e consciente para ele. 
Entretanto, o trabalho da análise encontra sempre uma lacuna associativa entre esses dois personagens, que são separados por um estranhamento quando postos lado a lado, embora não se desconheçam - como acontece na histeria, em que o recalque possibilita o desconhecimento. É possível reconhecer uma incongruência e um paradoxo que deixa o próprio sujeito na perplexidade, pois não pode mais deixar de se implicar nele. À custa disso, conseguimos estabelecer uma lógica para esses atos, que se configuram como uma encenação que tem princípio, meio e fim.

$1^{\mathrm{o}}$ ato, o princípio: na semana que o antecede, em meio à rotina do trabalho, ele começa sentindo uma apatia, um humor triste, o peso de uma vida sem vida, pois a falta de dinheiro o impede de desejar qualquer coisa, inclusive de se alegrar e ter uma namorada. Sua vida é medíocre, sem prazeres e sem objetivos.

Nessa atmosfera de frustração e angústia cada vez mais intensa, ele começa a ter flashes do prazer com as prostitutas. As fantasias se tornam mais freqüentes e, se um amigo o convidar para sair, alguns copos de cerveja são suficientes para deflagrar o processo. De repente, ele some. A cena se precipita como um ato acéfalo. Sem pensar.

$2^{\circ}$ ato, o meio: nesta cena, ele pode tudo. $\mathrm{O}$ dinheiro e sua falta não são problema. Não há limite, não há tempo, ali ele pode pegar qualquer mulher, pode beber, fumar, cheirar, comer tudo e todas; sentir-se o homem poderoso, o neto viril, que tem o direto de gozar sem exceção. Ele é a exceção, não está submetido á castração.

$3^{\circ}$ ato, o fim: ele "cai na real". Poderíamos dizer que ele sai da cena porque cai do real e cai como dejeto; não como falo.

Esse processo é, sem dúvida, muito parecido com as oscilações entre mania e depressão em alguns melancólicos e com a depressão descrita por Roland Chemama como a grande neurose da modernidade ${ }^{24}$, onde ele propõe uma relação entre certas atuações impulsivas e a clivagem do eu, como uma forma de defesa contra a depressão.

Entretanto, a análise demonstrou a diferença entre depressão e masoquismo do melancólico, e o masoquismo perverso pela erotização da pulsão de morte, que se apresenta recortada em episódios, como este, desconectados do quadro geral da vida do sujeito, na medida em que respondem especificamente à questão da castração feminina.

Por isso foi possível concluir, neste caso, que não estamos no campo da neurose nem da psicose. O recurso que promoveu resultados foi marcar no discurso esse modo de lidar com

\footnotetext{
${ }^{24}$ Chemama; 2007.
} 
a fantasia onde se desmente a castração através da divisão do eu em dois personagens paradoxais que convivem, sem que um possa excluir o outro para poder se unificar, sempre que a vontade de gozar excede o desejo de viver.

A partir desse manejo, foi possível desvelar a realização da fantasia ao modo de atuação perversa, ou seja, como mecanismo de anulação da contradição. No momento de surgimento da angústia devido à impotência imaginária diante da mulher "séria", o sujeito recorre à fantasia que, assim como na alucinação do bebê, não dá conta de satisfazer ou de barrar a força cumulativa do seu impulso. Como não encontra, em seu instrumental simbólico, um suporte propício ao recalcamento ou para metaforizar a satisfação em um substitutivo sublimatório, só lhe resta desmentir a castração e agir sem que nada seja capaz de impedi-lo de realizar o ato. Por este ato, ele desmente a falta do falo em si e na figura materna.

Podemos, além disso, ver neste ato um desafio à lei na medida em que interroga o sentido de ausência do pai como agente da castração. A denúncia implícita da pére-version, da inércia de um pai impassível diante de suas saídas desastrosas, excluído de qualquer implicação com o que acontece diante de seus olhos, expõe este olhar oco que existe tanto nele quanto no pai, anônimo e inanimado, agente apático.

Nesse modo de pensar e agir, reconhecemos o roteiro que repete um motivo latente no qual o "sou castrado" assim como "a mulher não tem o falo" estão elididos; em que ele não é ele - não tem nome - e a prostituta encarna o objeto inanimado de gozo que presentifica e se confunde com a imagem do próprio falo: fetiche que sustenta sua armação; sujeito e outro despersonalizados, do mesmo modo que, na fantasia, "bate-se numa criança".

Aqui podemos ver como a estrutura do fantasma perverso, propriamente dito, diferencia-se claramente da fantasia perversa do neurótico a partir da forma como o roteiro fantasmático se apresenta

[...] recortado e destacado da história do sujeito, como se fosse uma seqüência de cenas sedutoras de um filme, desconectadas de seu enredo completo, o que determina sua fixidez e a posição de certeza de saber como se dá a captura do objeto de gozo. O sujeito perverso situa-se em uma economia psíquica que lhe permite se assegurar da presença total, despudorada e direta do objeto de gozo, e em uma relação explícita e desvelada com o outro, oscilando entre essa presença positiva e absoluta do objeto ou sua ausência insuportável e desestabilizadora. ${ }^{25}$

No encontro com a ausência/presença do falo e com a sua própria castração diante da mulher, nosso jovem sujeito desaparece de repente para dar consistência à afirmação de que

\footnotetext{
${ }^{25}$ Fleig; 2008. p. 35.
} 
não há castração, partindo de outro lugar. Mas ele não vai porque assim o deseja, é a vontade de gozo desse eu anônimo que entra em cena e o conduz aonde não há empecilhos e a satisfação é certeza. A entrada em análise de dá quando este anonimato, até então preservado, começa a ser ameaçado por um corte: primeiro, quando ele se vê obrigado a recorrer aos amigos; segundo, quando o envolvimento com marginais, que podem identificá-lo, o conduz um passo adiante na direção de desafio à morte.

O progresso da análise vai tornar evidente o caráter compulsório, mortificador e destrutivo desse gozo em que o sujeito se perde de seu desejo, assujeitado a essa outra regra que o condena ao apagamento nessa dimensão do anonimato. A idéia de negativo da liberdade é perfeita para esta situação ${ }^{26}$.

Mário Fleig considera que a cultura contemporânea exerce um papel preponderante na elaboração desses roteiros:

Propomos, como hipótese, que a dessubjetivação do sujeito moderno tem incidência no que constitui um dos fenômenos elementares da perversão. A noção de fenômenos elementares advém da psiquiatria clássica, e Lacan tenta mostrar que não se trata apenas de um fato ou acontecimento, mas de um motivo que se repete, muitas vezes de formas disfarçadas, e que se encontra no interior do delírio, na psicose ou no roteiro perverso como o modo de relação do sujeito com o objeto. [...] São fenômenos sutis, uma espécie de aura, impressões, um sentimento, uma estranheza que antecede o desencadeamento do delírio ou das alucinações. [...] essa dessubjetivação no campo da perversão aparece na paixão pelo inanimado [...] Aparece também na crescente disseminação das formas de anonimato na contemporaneidade. O sujeito se coloca em situações em que seu nome não aparece, o que não se restringe apenas à clandestinidade. São fenômenos aparentemente banais, mas que podem indicar aquilo que diz respeito aos fenômenos elementares da perversão ${ }^{27}$.

E, mais adiante, ele propõe outras questões que nos conduzem a uma mais ampla dimensão.

Um aspecto interessante é a interrogação que o sujeito perverso introduz no campo das normas sociais: é um sujeito que se situa fora das normas e quer impor suas próprias normas? Seria um sujeito fora-da-lei e que, ao mesmo tempo, impõe uma outra lei? Qual é o estatuto da lei? Não estaria ele mesmo submetido a essa outra lei, ou seja, uma espécie de roteiro pelo qual está tomado e que precisa do outro para ser colocado em cena?

O próprio sujeito perverso está submetido a um roteiro particular, ele segue uma lei muito mais rígida do que as leis que ele contesta. [... $]^{28}$

\footnotetext{
${ }^{26}$ Roudinesco; 2008. p. 10-11.

${ }^{27}$ Fleig; 2008. 59-60.

${ }^{28}$ Fleig; 2008. 59-60.
} 
Não podemos deixar de concordar que tudo isso é propiciado pela cultura em que vivemos, onde o anonimato e o inanimado oferecem ao sujeito meios de gozo que passam a ser normais, desejáveis, senão compulsórios, para aqueles que pretendem demonstrar uma virilidade, provando resistência na busca desenfreada de um prazer absoluto, a qualquer custo.

Podemos também nos interrogar sobre o que poderia levar sujeitos que contam com esse tipo de arranjo psíquico a se engajar no discurso analítico. Talvez o fracasso da proteção contra a angústia seja o motivo privilegiado para levar um perverso ao divã. No caso desse jovem, a tentativa de barrar esta atuação começa quando ele percebe que o prazer a que se expõe o conduz ao mais além do prazer: compulsão mortificante, caminho da sua destruição. Mas isto só se opera a partir da falta de continuidade que a análise introduz entre os dois personagens resultantes da clivagem.

Ao contrário do chavão de que perversos não se analisam, tenho a suspeita de que há mais sujeitos perversos nos divãs do que se tem notícia. Pois a perversão não se limita aos casos de perversidade psicopática que encontramos nas páginas policiais, ou na literatura, onde grandes perversos mostram sua habilidade para sublimar e criar obras de arte. É possível que muitos casos mascarados como depressão ou melancolia na verdade se sustentem nesse modo particular de relação com a linguagem, que nem sempre é detectado porque o desejo perverso se aproxima da fantasia perversa do neurótico em relação a instituir a nãocontradição como lei.

Catherine Millot inicia seu livro Gide Genet Mishima. Inteligência da perversão, com um capítulo intitulado "Um talento perverso" em que ela trata dessa inclinação para os extremos que, apesar das diferentes formas de se apresentar, une todos os perversos em um mesmo desafio ao princípio supremo da razão, que é a lei da não-contradição. Ela ressalta esta habilidade particular do perverso de transmutar o sofrimento em gozo e a falta em plenitude, que coincide com uma das vocações da arte. Ela diz que "[...] eles têm a arte de fazer de necessidade virtude e uma faculdade de vencer a infelicidade que é um assunto de estilo. Aqui, a língua os leva, suas ambigüidades, suas inversões, seus equívocos profundos" 29 .

O perverso tem a "arte" de criar o sublime e o abjeto, sem contradição. A representação do feminino enquanto falta faz dele algo abjeto, mas ao mesmo tempo sublime, ao revesti-lo dos inúmeros objetos que sugerem o falo. Do sublime ao abjeto, a conseqüência

${ }^{29}$ Millot; 2004. p.7. 
lógica do desmentido da castração feminina, é que a diferença sexual não existe. $\mathrm{O}$ feminino, que só pode se representar pela ausência, desaparece na abjeção e isto interessa, particularmente, à histérica cuja inveja do pênis remete ao desejo de ter o falo, negando a castração. Não podemos nos esquecer que, quando Freud diz que a neurose é o negativo da perversão, ele especifica que se trata sempre da neurose histérica. A histeria é o inverso da perversão, tanto no sentido de que o sujeito histérico é aquele que mais facilmente se deixa seduzir pela promessa perversa, como no sentido de que o histérico é quem se revolta contra o avanço do saber impessoal e dessubjetivado da ciência moderna e da técnica, no que ele tem a ver com a estrutura da perversão.

A perversão e o desejo perverso estão determinados por um modo particular de gozo que diz respeito ao sujeito constituído no contexto da ciência moderna, e por isso concerne a todos nós ${ }^{30}$.

Ironicamente ou não, a teoria freudiana, ao lançar um novo olhar sobre a perversão, precipita um novo olhar sobre a própria cultura. Desta forma, quando a psicanálise inclui aquilo que estava excluído por questões morais, religiosas e de convenção, ela caminha num sentido contrário ao movimento que culmina com a exclusão radical deste termo pela ciência médica moderna. Este novo olhar inaugura uma visão do humano calcada na relativização dos parâmetros absolutos; e isto não deveria ser ignorado pelo conhecimento científico, principalmente pelo que isto permite pensar a respeito da própria ciência moderna.

Sabemos do interesse de Freud em ver a psicanálise reconhecida como ciência, pois, além de ser um cientista oriundo da neurologia, ele necessitava deste reconhecimento para que suas teses não fossem ignoradas.

Para que a psicanálise não fosse confundida com práticas espúrias, místicas ou impuras - e até perversas -, era preciso enquadrar-se nos padrões da ciência tradicional. Esta qualificação foi fundamental, sem a menor dúvida, para a sobrevivência da psicanálise naqueles tempos difíceis em que a chancela da tradição científica representava o selo de qualidade de nossos dias.

Entretanto, ao final do seu percurso teórico, vemos que essa preocupação se rarefaz, e ele propõe a psicanálise leiga, liberta e diferenciada dos cânones da ciência médica e da religião. Neste momento em que a teoria avançou suficientemente e ainda mais hoje, nos tempos da ciência médica moderna, fica muito clara a oposição fundamental entre o objeto da

${ }^{30}$ Fleig; 2008. p. 109. 
ciência e o objeto da psicanálise, pois o indivíduo, que ocupa o lugar de objeto da ciência, é aquele que ocupa o lugar de sujeito para a psicanálise. O cientista é o sujeito da experiência, o analista é o objeto na transferência analítica. A participação do sujeito, fundamental na experiência analítica, deve abster-se na experiência científica, deve permanecer ausente em nome da neutralidade científica.

Mas há outro motivo fundamental para justificar que os analistas não se interessem em aproximar a psicanálise da ciência moderna, que tem a ver com a perversão social da modernidade, à qual se refere Fleig no trecho que citei há pouco. Segundo ele,

[...] a modernidade forneceu as condições sociais e subjetivas para o surgimento de sujeitos perversos: a impessoalização e dessubjetivação dos discursos, isto é, o advento do individualismo e da massa, que corresponde à foraclusão do sujeito da enunciação no discurso da ciência. $^{31}$

Lacan sinaliza, no "Discurso de Roma", esta cisão das relações entre a fala e a linguagem no contexto da ciência moderna, que tem como conseqüência - como hoje observamos - a classificação do DSM, que abandonou a terminologia psicanalítica, psicodinâmica ou fenomenológica, que humanizava a psiquiatria, substituindo-a por parâmetros comportamentais em que a subjetividade está excluída ${ }^{32}$.

Neste contexto da ciência atual, o sujeito perde seu sentido, é anônimo, quantificado, pois o saber é dessubjetivado e universalizante. É um tipo de saber no qual encontramos a linguagem sem fala, a antinomia do sujeito cindido entre dois discursos. Este ideal de objetivação universalizante subverte o campo da ciência tanto quanto o social, na medida em que nega radicalmente a alteridade do outro e o instrumentaliza promovendo o apagamento da dimensão empática do semelhante para privilegiar a dimensão do estranho, do individualismo. Daí o incremento da violência nas relações sociais em nossos dias.

Esse princípio supremo da razão, em nome da pretensão de dar conta de suas condições; da exclusão da diferença, sob o pretexto de uma justiça igualitária e fraterna; da redução do corpo à categoria de organismo a ser usado, estudado ou explorado, em nome de um Saber supremo, ou de uma qualidade total, ou de uma submissão apática e amoral na execução de um trabalho, todos estes princípios, em nada diferem do princípio fundamental

\footnotetext{
${ }^{31}$ Fleig; 2008. p. 119.

${ }^{32}$ Sobre esta questão, ver Roudinesco, 2008. p. 187. 
da perversão: o do direito a gozar do outro e de seu corpo, tal como se afirma na máxima sadiana, que visa o absoluto na exclusão da diferença, para desmentir a impossibilidade ou, se preferirem, a castração.

É isso que, em última instância, busca o perverso, restaurar o Ser supremo [...] A obturação radical da falta, em todos os furos possíveis, se transmuta no ódio radical por aquela que denuncia o furo: A Mulher. O perverso se estrutura em torno do repúdio radical ao outro sexo, que exige sempre velado e até mesmo danificado, para que nada possa vir de lá. Mais do que isso, visa a destruir tudo que possa ter passado pelo sexo feminino, inclusive ele mesmo. Aí se encontra a única saída para a realização da paixão perversa, que o aspira a eliminar-se a si mesmo. ${ }^{33}$

É nesse sentido que, ao discurso da psicanálise, não interessa se harmonizar com o discurso da ciência, desde quando aquilo que a análise visa - o rochedo da castração - é exatamente o que ela trabalha para excluir de seu campo, por não saber que isto a incita a eliminar-se a si mesma.

Desafortunadamente, os ouvidos moucos e os olhos ocos da ciência moderna não podem ouvir e ver-se em sua trajetória perversa rumo à própria decadência. Mas os perversos que se deparam e engajam suas angústias no trabalho analítico, certamente podem ter uma chance.

Que faríamos sem Sade, Mishima, Jean Genet, Pasolini, Hitchcock e muitos outros, que nos deram as obras mais refinadas possíveis? Que faríamos se não pudéssemos apontar como bodes expiatórios - isto é, perversos - aqueles que aceitam traduzir em estranhas atitudes as tendências inconfessáveis que nos habitam e que recalcamos? ? $^{34}$

Elizabeth Roudinesco

\section{REFERÊNCIAS}

André S. A Impostura perversa. Rio de Janeiro: Jorge Zahar; 1995. p. 311-312.

Barbieri C. A postura perversa é a impostura. In: Estudos de Psicanálise. Círculo Brasileiro de Psicanálise; 2007. v.30 p. 35-42.

Barbieri C. O viés perverso da sexualidade. In: Cogito. Círculo Psicanalítico da Bahia, 2003. v.5 p. 11-17.

Chemama R. Depressão, a grande neurose contemporânea. Porto Alegre: CMC; 2007.

\footnotetext{
${ }^{33}$ Fleig. 2008. p. 143-144.

${ }^{34}$ Roudinesco; 2008. p.13. 
Fleig M. O desejo perverso. Porto Alegre: CMC; 2008. p. 15.

Freud S. A divisão do ego no processo de defesa [1940(1938)]. In: __. Edição Standard das Obras Psicológicas Completas. Rio de Janeiro: Imago; 1976. v. XXIII.

Freud S. Cinco lições de psicanálise [1910 (1909)]. In: .Edição Standard das Obras Psicológicas Completas; 1976, v. XXI.

Freud S. Conferências introdutórias sobre psicanálise [1916-1917]. In: __..Edição Standard das Obras Psicológicas Completas.. Rio de Janeiro: Imago; 1976. v. XVI, p. 359.

Freud S. Esboço de Psicanálise [1940(1938)]. In: __. Edição Standard das Obras Psicológicas Completas.. Rio de Janeiro: Imago; 1976. v. XXIII

Freud, S. Totem e tabu (1913[1912]). In: Obras Completas. 3.ed. Madrid: Biblioteca Nueva; 1973. v. II

Freud, S. Tres ensayos para una teoría sexual [1905]. In: Obras Completas. 3.ed. Madrid: Biblioteca Nueva; 1973. v. II, p. 1.172.

Freud S., "Uma Criança É Espancada - Uma Contribuição ao Estudo da Origem das Perversões Sexuais", In:___. Edição Standard das Obras Psicológicas Completas. Rio de Janeiro: Imago, 1976; v. XVII.

Lacan, J. Kant com Sade. In: ___ Escritos. Rio de Janeiro: Jorge Zahar, 1988; p.780.

Lacan Jacques. O seminário, livro 4: a relação de objeto [1956-1957]. Rio de Janeiro: Jorge Zahar, 1995; p. 156.

Lacan Jacques. O seminário, livro 5: as formações do inconsciente. Rio de janeiro: Jorge Zahar; 1999. p. 239.

Littré Émile. Dictionnaire de la langue française. Paris: Gallimard-Hachette; 1966. v.5. Grifo nosso.

Millot C. Gide Genet Mishim: inteligência da perversão. Rio de Janeiro: Companhia de Freud; 2004.

ORGANIZAÇÃO MUNDIAL DE SAÚDE. Classificação de transtornos mentais e de comportamento da CID-10: descrições clínicas e diretrizes diagnósticas. Porto Alegre: Artmed; 1993.

Pimentel D, ARAÚJO, M.(Org.) Interfaces entre a Psicanálise e a Psiquiatria. Aracajú: Círculo Brasileiro de Psicanálise; 2008. 300 p.

Roudinesco E. A parte obscura de nós mesmos: uma história dos perversos. Rio de Janeiro: Jorge Zahar; 2008. p.7. 